\title{
DOI 10.26886/2414-634X.4(23)2018.3
}

UDC: 666.942:691.535

\section{INFLUENCE OF AGGRESSIVE ENVIROMENT ON DURABILITY OF PORTLAND CEMENT BASED DRY BUILDING MIXTURES}

\section{Tokarchuk, PhD in Technical Sciences \\ Y. Kovalenko, engineer}

National Technical University of Ukraine "Igor Sikorsky Polytechnic Institute", Ukraine, Kyiv

The corrosion resistance of dry building mixtures on the basis of Portland cement of general construction purpose was considered. The choice of types of dry building mixtures for research was substantiated. Their physical and mechanical properties and corrosion resistance in the conditions of contact with various aggressive environments have been studied. It has been established that the corrosion resistance of dry building mixtures depends not only on the properties of the original cement, but also on the composition of the mixtures themselves. Significant impact on the stability index has the appearance of an aggressive solution. An increased corrosion resistance of the mixture which contains a polymeric component in its composition, had been noted.

Key words: dry building mixtures, portland cement, stucco, tile adhesive, corrosion resistance

Foreword. Nowadays, cement is one of the most common structural materials. It has proved by itself as the most durable and fully used material for the construction industry [1].

The tendency to corrosion damage is one of the main disadvantages of construction materials, especially cement mixtures and concrete, the elimination of which causes considerable material costs. 
Depending on the nature of substances contained in water, their impact on the durability of concrete occurs in different ways. V. M. Moskvin [2] separates the corrosive processes occurring in concrete under the influence of the aqueous environment into three types:

I - corrosion due to dissolution with subsequent filtration through the thickness of concrete components of cement stone (so-called leaching) under the influence of water with a small temporary hardness,

II - corrosion under influence of water containing substances that undergo in exchange reaction with components of a cement stone with formation either easy-soluble (washed out by water) or low-soluble amorphous masses, which have astringent properties of products that weaken the structure of cement stone,

III - corrosion, in which in pores and capillaries of cement stone, due to exchange reactions, accumulate and crystallize substances that cause internal stress and destruction.

Secondary protection against corrosion consist in creation of conditions that limit or exclude the impact of aggressive environment on concrete or reinforced concrete structures after their manufacture [3]. There are many different methods of protecting the surface of structures [4]. It is a variety of paint and varnish coatings, facing materials, hydrophobic solutions, and more.

The basis of dry building mixtures (DBM) are binder (portland cement, aluminat cement, gypsum, lime, also neutral fillers and special chemical additives, which give a mixture of its properties [5]. Neutral additives are contained in dry building mixtures in a significant amount and has substantial effect on its properties. It is well known that the nature of the curing processes is influenced not only by the chemical but also by the structural composition of these additives [6]. In addition, it has been 
established that on corrosion resistance affects even the type of carbonate component [7].

The presence of additional components leads to the need to study the corrosion resistance of dry building mixtures based on Portland cement of general construction purpose, due to the fact that the corrosion of these materials will be different from the rather well studied processes that occur when corrosion of the cement stone.

Purpose and tasks of research. The purpose of the work is to study the influence of aggressive environments on the strength characteristics and corrosion resistance of dry building mixtures.

This requires:

- to study the physical and mechanical properties of dry building mixtures;

- determine the coefficients of stability of dry building mixtures in different types of aggressive solutions.

Objects and methods of research. In this study, the impact of various aggressive media on the corrosion resistance of plaster cementpolymer, cement-lime plaster and tile adhesive are considered. The choice of these materials is explained by the fact that, firstly, they all contain Portland cement as a constructional component, and secondly, their main purpose is the protection of the structures from the environmental impact. The main reason for the destruction of concrete, as already noted, is the impact of the aggressive environment due to the entry of moisture on the surface of the stone and subsequent penetration into the middle of the product, so the use of stucco or tile adhesives is one of the budget options for protecting surfaces from corrosion.

The main physical and mechanical properties of the mixtures were determined according to the method used for the investigation of Portland cements of general construction purpose [8]. 
Determination of the stability of materials to the aggressive environment was carried out in accordance with the methodology proposed by the Research Institute "Giprocement" and Research Institute "Cement" [9]. Prepared samples of cement and mixtures was kept in aqueous environment for 28 days. During this period, samples was tested for compression strength at the age of 2, 7 and 28 days. After 28 days of hardening all samples were placed: control samples in water, and project samples - in four aqueous solutions: 3.0 mass $\%-\mathrm{Na}_{2} \mathrm{SO}_{4}, 3.0$ mass $\%$ $\mathrm{MgSO}_{4}, 0.2$ mass\% $-\mathrm{CaSO}_{4}$ and "sea water" (a mixture of $\mathrm{NaCl}$ salts - 8.0 of $\mathrm{mass} \%, \mathrm{MgSO}_{4}$ - of mass $0.7 \%, \mathrm{MgCl}_{2} 1.0$ of mass $\%$, and $\mathrm{CaSO}_{4} 0.3$ of mass $\%$ per $100 \mathrm{ml}$ of water). Resistance to each type of corrosion was evaluated by determining the coefficient of stability, which is defined by the ratio of the strength of the samples that were stored in the aggressive solution to the strength of the samples that were stored in water at the age of 6 months.

Research results. Table 1 shows the results of determining the strength of selected types of dry building mixtures. It should be noticed that the strength of cement samples is much higher in all curing periods than the similar indicators in the materials under research. This is explained due to the fact that in the composition of dry building mixtures contains a significant number of neutral and organic additives, which leads to the effect of "dilution" of cement and, consequently, to the reducing the strength of the samples.

Table 1

Comparative characteristics of the strength of cement-polymer and cement-lime binders, tiles adhesive and cement

\begin{tabular}{|l|c|c|c|}
\hline \multirow{2}{*}{ Matherials } & \multicolumn{3}{|c|}{ Compressive strength, MPa } \\
\cline { 2 - 4 } \multirow{2}{*}{$\begin{array}{l}\text { Mens } \\
\text { Cement }\end{array}$} & 13,0 & 7 days & 28 days \\
\hline
\end{tabular}




\begin{tabular}{|l|c|c|c|}
\hline Cement-polymer mortar & 5,5 & 15,1 & 21,1 \\
\hline Cement-lime mortar & - & 1,0 & 2,4 \\
\hline Tiles adhesive & - & 2,8 & 7,8 \\
\hline
\end{tabular}

Table 2 shows the results of determining the strength of selected materials that were in aggressive solutions.

Table 2

Strength of samples of dry building mixtures in aggressive solutions

\begin{tabular}{|c|c|c|c|c|c|c|}
\hline \multirow{3}{*}{ Matherials } & \multicolumn{6}{|c|}{ Strength, MPa } \\
\cline { 2 - 7 } & Days & Water & $\mathrm{Na}_{2} \mathrm{SO}_{4}$ & $\mathrm{MgSO}_{4}$ & $\mathrm{CaSO}_{4}$ & $\begin{array}{c}\text { Marine } \\
\text { water }\end{array}$ \\
\hline \multirow{2}{*}{$\begin{array}{c}\text { Cement-polymer } \\
\text { mortar }\end{array}$} & 28 & 21,1 & 21,1 & 21,1 & 21,1 & 21,1 \\
\cline { 2 - 7 } & 60 & 15,5 & 17,3 & 16,0 & 15,5 & 11,5 \\
\cline { 2 - 7 } & 180 & 13,5 & 16,5 & 14,8 & 12,3 & 9,0 \\
\hline \multirow{2}{*}{$\begin{array}{c}\text { Cement-lime } \\
\text { mortar }\end{array}$} & 28 & 2,4 & 2,4 & 2,4 & 2,4 & 2,4 \\
\cline { 2 - 7 } & 180 & 2,9 & 2,1 & 3,8 & 3,1 & 2,5 \\
\hline \multirow{3}{*}{ Tiles adhesive } & 28 & 7,8 & 7,8 & 7,8 & 7,8 & 7,8 \\
\cline { 2 - 7 } & 180 & 8,6 & 7,4 & 7,8 & 9,6 & 6,9 \\
\cline { 2 - 7 } & 10,0 & 6,3 & 4,0 & 8,5 & 6,8 \\
\hline
\end{tabular}

It should be noted that the composition of dry building mixtures significantly affects the strength of the samples. Thus, the strength of cement-polymer binder samples in the water is gradually reduced, as opposed to two other materials. But in the conditions of the solution of sodium sulfate and magnesium in this stucco, an increase in the coefficient of stability is observed (Fig. 1). Some increassng of this coefficient is noted in cement-lime stucco in a solution of calcium sulfate. Additional research is needed to find out the causes of this phenomenon. In all other solutions, the 
coefficient of stability is significantly reduced, especially in the conditions of "sea water".

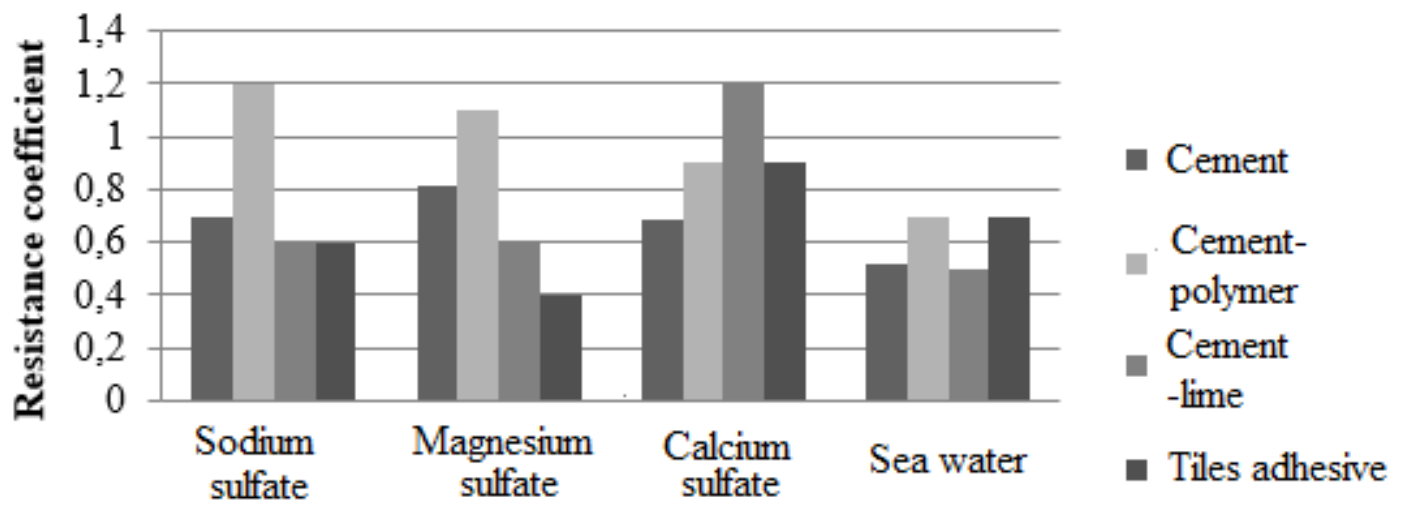

Type of aggressive solution

Fig. 1. Coefficient of corrosion resistance of dry building mixtures at the age of 180 days.

There is a higher corrosion resistance of cement-polymer stucco in almost all types of aggressive solutions. The sharp increase of this coefficient for cement-lime mortar in conditions of aggression of calcium sulfate may be due to the fact that in this case there are additional calcium ions.

The greatest reduction in strength is observed in samples of tile glue in solutions of sodium sulfate and magnesium sulfate, which is clearly visible in fig. 2.

Tiles adhesive has residual strength, but there is a surface fracture of the samples. For comparison, the appearance of samples of cementpolymer stucco, which completely preserved the original appearance, are presented.

If we compare resistant coefficient of the original cement with the coefficients of dry building mixtures (Figure 2), then we can conclude that its stability is higher only in the conditions of sodium sulfate and magnesium, in other aggressive solutions it is lower. This confirms that the 
corrosion resistance of dry building mixtures affects the component of their composition.

Tiles adhesive

Cement-polymer

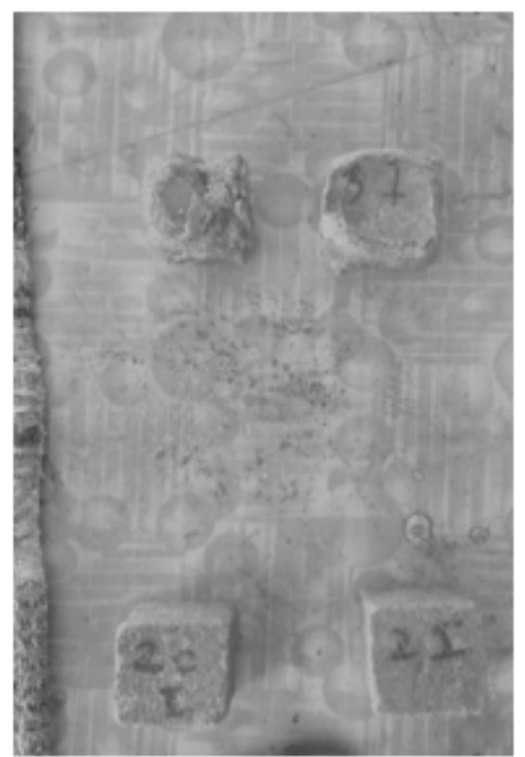

Sodium sulfate

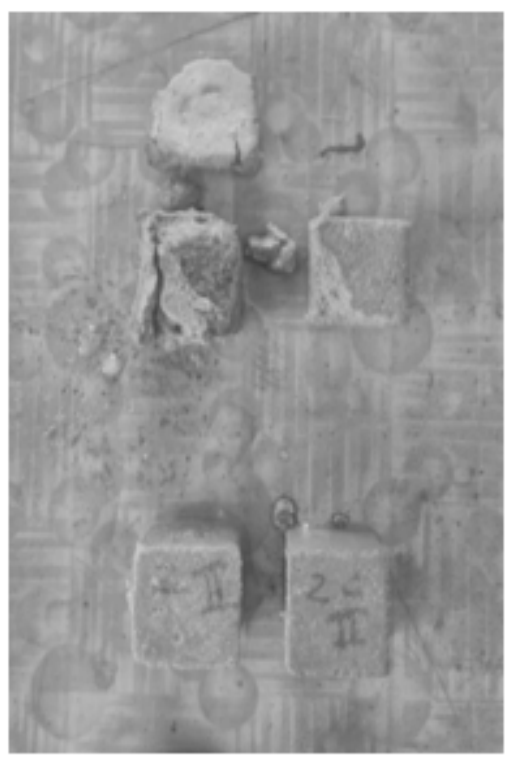

Magnesium sulfate

Fig. 2. Appearance of adhesive samples for tile and cementpolymer plaster after 180 days hardening in solutions of sodium sulfate and magnesium sulfate

The obtained results testify to the necessity of carrying out additional researches in order to determine the reasons that lead to corrosion of construction materials on the basis of cements. Especially it is necessary to pay attention to the fact that increased corrosion resistance marks in DBM with the use of a polymeric component.

\section{Conclusions.}

1. Physical and mechanical properties of dry building mixtures are somewhat different from the similar properties of cements. First of all, it concerns strength indicators, which in all selected mixtures is much lower, which is most likely due to the effect of "diluting" cement with neutral and organic additives. 
2. The corrosion resistance of dry building mixtures depends not only on the properties of the original cement, but also on the composition of the mixtures themselves. Significant impact on the stability index has the appearance of an aggressive solution.

\section{References:}

1. Teoriya tsementa [Tekst] : ucheb, posobie / A. A. Pashchenko, V. S. Gumen, V.V. Chistyakov, i dr. - K.: «Budivelnik», 1991, 168 s.

2. Korroziya betona $i$ zhelezobetona $i$ metody ikh zashchity [Tekst]: ucheb. / Moskvin V. M., Ivanov F. M., Alekseev S. N., Guzeev Ye. A. - M.: Stroyizdat, 1980. - 533 s.

3. Voylokov I. A. Vtorichnaya zashchita betonnykh i zhelezobetonnykh konstruktsiy [Tekst] / I. A. Voylokov // EKSPOZITSIYA. Betony \& Sukhie smesi. - 2008. - № 60. - s. 8-10.

4. Kondrashhenko O. V. Konspekt lekcij z kursu «Korozija ta zakhyst budiveljnykh materialiv ta konstrukcij» (dlja studentiv 5 kursu usikh form navchannja i slukhachiv drughoji vyshhoji osvity osvitnjo-kvalifikacijnogho rivnja specialist, maghistr za specialjnistju "Promyslove ta cyviljne budivnyctvo») / O. V. Kondrashhenko; Kharkiv. nac. un-t misjk. ghosp-va im. O. M. Beketova. - Kh.: KhNUMGh im. O. M. Beketova, 2016. -85 s.

5. Kozlov V. V. Sukhie stroitelnye smesi [Tekst] : ucheb. posobie / V. V. Kozlov - M.: Izdatelstvo ASV, 2000. - 6 str. s il.

6. Sokoljcov V. Ju., Tokarchuk V. V., Svidersjkyj V. A. Osoblyvosti tverdnennja kompozycijnykh cementiv z sylikatnymy dobavkamy riznogho pokhodzhennja (2015). I EasternEuropean Journal of Enterprise Technologies, 3 (11), str. 9-14.

7. Tokarchuk V. V., Kovalenko Ju. O. Korozijna stijkistj cementiv z karbonatnymy dobavkamy / Mizhnarodnyj naukovyj zhurnal "Naukovyj oghljad». - 2018. - № 4 (47). - S.39-48. 
8. DSTU B V.2.7-187:2009 «Cementy. Metody vyznachennja micnosti na zghyn i stysk» [Tekst]. - Chynnyj vid. 01.08.2010. - Kyjiv: Minreghionbud Ukrajiny, 2010.

9. Butt Yu. M. Praktikum po tekhnologii vyazhushchikh veshchestv. - M.: Vissh. shk., 1973. - 504 s. 